\title{
Evaluation of yield performance of Lentil (Lens culinaris Linn) through Cluster Front Line Demonstration in Darbhanga District of Bihar, India
}

\author{
Ram Prawesh Prasad ${ }^{1 *}$, D. Shekhar ${ }^{1}$, M.S. Kundu ${ }^{2}$, \\ Amba Kumari ${ }^{1}$ and Chandan Kumar ${ }^{1}$
}

\author{
${ }^{1}$ Krishi Vigyan Kendra, Jale, Darbhanga (Bihar)-847302 (Dr. Rajendra Prasad Central \\ Agricultural University, Pusa, Samastipur, Bihar) 848125, India \\ ${ }^{2}$ Director Extension Education (Dr.Rajendra Prasad Central Agricultural University, \\ Pusa, Samastipur, Bihar) 848125, India
}

*Corresponding author

K e y w o r d s
Yield gap,
Extension gap,
Technology gap,
Technology index,
CFLD, Pulses,
B:C:R
Article Info
Accepted:
18 July 2020
Available Online:
10 August 2020

A B S T R A C T

Pulses, an important constituent of food grains, play a vital role in food and nutritional security of millions of down trodden people of the world. Being an important source of protein, poor people mostly depends on pulses for meeting their daily requirements of this essential nutrient. Pulses will form a major source of protein for a huge section of Indian particularly, for the poor, backward classes of the traditionally vegetarian population (Reddy, 2004). But in reality, the net availability of pulses has come down from 61 to $37 \mathrm{gm} /$ day/person and daily per capita consumption has come down from about 74 grams to 23 grams during the period 1960-61 to 2009-10 as against the ICMR norms of $40 \mathrm{gm} /$ day/ person over the period 1950-51 to 2008-2009 in India. The data outputs were collected from both CFLD plots as well as control plots (farmers practices) and finally the extension gap, technology gap, technology index along with the benefit cast ratio. The result of Cluster Front Line Demonstrations convincingly brought out that the yield of lentil could be increased by $21 \%$ to64.35\% with the intervention of balanced nutrient coupled with the improved seed and disease management in the Darbhanga district of Bihar. The input and output prices of commodities prevailed during each year of demonstration were taken for calculating cost of cultivation, net return and benefit cost ratio. From the above finding, it can also be concluded that use of scientific methods of lentil cultivation can reduced the technology gap to a considerable extent thus leading to increased productivity of the district. Moreover, extension agencies in the district need to provide proper technology support to the farmers through different educational and extension methods to reduce the extension gap for higher pulses production in the Darbhanga district of Bihar. 


\section{Introduction}

Pulses, an important constituent of food grains, play a vital role in food and nutritional security of millions of down trodden people of the world. Being an important source of protein, poor people mostly depends on pulses for meeting their daily requirements of this essential nutrient. Pulses will form a major source of protein for a huge section of Indian particularly, for the poor, backward classes of the traditionally vegetarian population (Reddy, 2004). But in reality, the net availability of pulses has come down from 61 to $37 \mathrm{gm} /$ day/person and daily per capita consumption has come down from about 74 grams to 23 grams during the period 1960-61 to 2009-10 as against the ICMR norms of 40 $\mathrm{gm} /$ day/ person over the period $1950-51$ to 2008-2009 in India, although, the World Food Programme (WFP) includes 60 grams of pulses in its typical food basket alongside cereals, oils, sugar and salt due to huge demand-supply gap. India is reckoned as the largest producer and consumer of pulses in the world accounting 25 per cent of that global production, 27 per cent of consumption and 34 per cent of food use (Price et al., 2003). India is the largest producer, consumer and importer of pulses in the world. Pulses are important sources of protein, high in fiber content and provide ample quantity of vitamins and minerals. Keeping in view large benefits of pulses for human health, the United Nations had proclaimed 2016 as the International Year of Pulses.

Bihar one of the important pulses growing and consuming state in India contributes about 2.35 percent of area which is 7-8 percent of the gross cropped area in the state and 3.06 percent of production. The productivity of pulses range between 819 $\mathrm{kg} / \mathrm{ha}$ in $2000-01$ to $897 \mathrm{~kg} / \mathrm{ha}$ in $2013-14$. It is mostly grown in rain fed condition and resulting in high yield fluctuation every year.
In India average yield of pulses in rice fallow system is about $11 \%$ higher than national average, whereas in Bihar it is higher than $30 \%$ and in Madhya Pradesh by $15 \%$ Traditionally pulses have been considered important elements of cropping systems in the Bihar, but with the introduction of irrigation and high profitability of alternative sources of soil nutrients in the form of inorganic fertilizers in 1960s, pulses were replaced or relegated to marginal lands and were substituted by high- yielding varieties of rice and wheat. Lentil predominantly is the rainfed crop grown in constrained environment. Several causes are responsible for low yield of lentil of which the use of traditional local cultivars, low plant density per unit area, weed infestation and poor crop management practices constitute the major ones. In this regard, the standard terminologies have been identified and defined. For example, yield potential (Yp), also called potential yield, is the yield of a crop cultivar when grown with water and nutrients non-limiting and biotic stress are effectively controlled (Evens, 1996, Van Ittersum and Rabbinge, 1997, Evans and Fischer, 1999). Potential yield depends on location as it relates to weather but is independent of soil, which is assumed to be physically and chemically favorable for crop growth.

\section{Materials and Methods}

The present study was carried out by Krishi Vigyan Kendra, Darbhnga during Rabi season from 2017-18,2018-19 and 2019-20 in the farmer's field of twelve villages Jogiara, Samdhinia, Sauria, Radhi, Manma, Kamtaul, Chandauna Sahaspur and Brahmpur from Jale block and Kolhanta patori, and Godaepatti from Hanumannagar block and Raje West from Manigachhi block of Darbhanga District. Total of 183 front line demonstrations on lentil were laid out comprising 183 farmers covering the total area of 60 ha with demonstration plots 
ranging from 0.40 ha. Under the cluster front line demonstrations improved technologies included improved variety (cv. - HUL 57), integrated nutrient management (20: 40: 20 kg N: P: K/ha) +Rhizobium + P.S.B. @ 500 g per ha, integrated pest management ( Seed treatment with FIR fungicide (Carbendazim $50 \%$ WP @ 2 gram $/ \mathrm{kg}$ seed), Insecticide (chloropyriphos 20\% E.C @5 ml/kg seed) and rhizobium culture and need based used of Saaf@1.0gram/ Lt of water for management of fungal infection and Imidachlopride 17.8 SL @ $1 \mathrm{ml} / 3 \mathrm{Lt}$ of water for aphid) were tested as intervention. Crop was sown between 25 October to 25 November with a spacing of $30 \mathrm{~cm} \mathrm{X} 5 \mathrm{~cm}$ and seed rate 30-35 $\mathrm{kg} / \mathrm{ha}$. Entire dose of $\mathrm{N}$ and $\mathrm{P}$ was applied as basal dose at the time of sowing. Under the demonstration programme farmer practice was maintain as control. Prior to conducting the front line demonstrations, group meeting and specific skill trainings were conducted. All other steps like farmer selection, site selection, farmer's participation etc was followed as suggested by Kirar et al., (2004) (Chaudhary, 1999; Venkatta Kumar et al., 2010). Materials for present study with respect to CFLDs and farmers practices has been given in Table 1. In case of local check plots, existing practices being used by farmers were followed. In general soil of area under study is sandy loam and medium fertility status.

Visits of farmers, the district agriculture line department and extension functionaries was organized at demonstration plots to disseminate the massage at large scale. The demonstrated farmers were facilities by KVK scientists in performing field operation like sowing, spraying, weeding, harvesting etc. during the course of training and visits. The necessary steps for selection of site and farmers layout of demonstrations etc., were followed as suggested by Chaudhary (1999). Traditional practices were mentioned in case of local checks. The data outputs were collected from both CFLD plots as well as control plots (farmers practices) and finally the extension gap, technology gap, technology index along with the benefit cast $\operatorname{ratio}(\mathrm{B}: \mathrm{C}: \mathrm{R})$ worked out (Sanui et al., 2000) as given below:

Technology gap $=$ Potential YieldDemonstration Yield

Extension gap $=$

Demonstration Yield - Farmers yield.

Potential Yield- Demonstration Yield

Technology Index = ---------------------- x100

Potential Yield

\section{Results and Discussion}

The result of 183 Cluster Front Line Demonstrations (CFLDs) conduct during 2017-18 to 2019-20 in 60ha area. On farmers field 12 village of Darbhanga district indicated that the cultivation practices comprised under-CFLD viz., used of improved variety (HUL-57), line sowing, balance used of fertilizers, sulphur, Zinc, weedicide, and control of lentil wilt through fungicide. Aphid problem through insecticides at economic threshold level, production on an average $44.68 \%$ more yield of lentil as compared to local practices $(9.82$ $\mathrm{q} / \mathrm{ha}$ ). The data of table 2 reveal that the yield of lentil fluctuated successively over the field of demonstrated plots. The maximum yield was recorded $14.87 \mathrm{q} /$ ha over local practices $(10.80 \mathrm{q} / \mathrm{ha})$. The increase in percentage of yield was range between $21 \%$ and $64.35 \%$ during three year study. The similar results of yield enhancement in rape seed crop in front line demonstrations has been documented by Mitra and Samajdar (2010), in tarai zone of west Bengal. The results are also in conformity with the findings of Tiwari and Saxena (2001), Tiwari et al., (2003) Tomer et 
al., (2003), Singh et al., (2007) and Katare et al., (2011). The results indicated that the Front line demonstrations has given a good impact on the farming community of this district as they were motivated by the improved agricultural technologies used in the front line demonstrations. The result clearly indicates the positive effect of CFLDs over the existing practices toward in enhancing the yield of lentil in Darbhanga, with its positive effect on yield attribute (Table 3). Benefit Cost ratio was recorded higher under demonstration against control of all the year of study. These results were also supported by The higher yield in demonstration plot may be attributed to the fact that farmers of demonstration plot have followed the same techniques that are used in research plot like line sowing, seed treatment with rhizobium, recommended fertilizer doses, plant protection measures, etc. Higher yield of chickpea and lentil in demonstration plot is due to line sowing with optimum spacing, improved variety with optimum seed rate, rhizobium inoculation, optimum fertilizer application and proper weed control (Rajiv and Singh, 2014). The demonstration conducted on lentil with improved varieties and technologies showed a yield advantage of about 33 per cent over local check (Kokate et al., 2013). Rhizobium inoculation alone can increase the yield of chickpea, pigeon pea, lentil and field pea by 12.5, 14.0, 18.1 and 20.6 per cent (Ali and Kumar, 2007), but in traditional system the sample farmers do not apply seed treatment with rhizobium resulting lower yield. Farmers did not practice seed treatment with rhizobium culture, an important component increasing the yield and yield attributes (Kumar and Elamathi, 2007). This type of gap arise when farmers deviate from the recommendation to achieve the agronomic yield potential Duwayri et al., (2000) The extension gap showed an increasing trend. The extension gap ranging between 2.28 to $5.58 \mathrm{q} /$ ha during the study period emphasizes the need to educate the farmers through various means for adoption of improved agricultural technologies to reverse the trend. The trend of technology gap (ranging between 0.43 to $2.22 \mathrm{q} / \mathrm{ha}$ ) reflects the farmers cooperation in carrying out such demonstrations with encouraging results in subsequent years. The technology gap observed might be attributing to the dissimilarity in soil fertility status and weather conditions. Mukharjee (2003), have also opined that depending on identification and use of farming situation, specific interventions may have greater implications in enhancing system productivity. Similar findings were also recorded by Mitra et al., (2010). The technology index, showed the feasibility of the evolved technology at the farmer's field. The lower the value of technology index, the more is the feasibility of technology. The wider gap in technology index (ranging between 2.81 and 14.50\%) during the study period in certain region, may be attributed to the difference in soil fertility status, weather condition, non-availability of irrigations water and insect- pests attack in the crop.

The benefit cost ratio of front line demonstrations have been presented in Table 3 clearly showed higher BC ratio of recommended practices was than control plots i.e. farmers practices in all the years of study. The benefit cost ratio of demonstrated and control plots were $3.38,3.00$ and 3.64 , and 2.82, 2.37 and 2.99 during 2017-18, 2018-19, 2019-20 respectively. Hence, favorable benefit cost ratios proved the economic viability of the interventions and convinced the farmers on the utility of interventions. Similar findings were reported by Sharma (2003) in moth bean and Gurumukhi and Mishra (2003) in sorghum. 
Table.1 Comparison between demonstration package and existing farmers practices under Lentil practices

\begin{tabular}{|c|c|c|}
\hline Particulars & Demonstration package & Farmers practices \\
\hline $\begin{array}{l}\text { Farming } \\
\text { situation }\end{array}$ & Irrigated medium land & Irrigated medium land \\
\hline Variety & HUL-57 & Local \\
\hline Time of sowing & 25 October to 25 November & 20 October to 05December \\
\hline $\begin{array}{l}\text { Method of } \\
\text { sowing }\end{array}$ & Line sowing $(30 \times 5 \mathrm{~cm})$ & Broad casting \\
\hline Seed rate & $30-35 \mathrm{Kg} /$ ha. & 40-45 Kg/ha. \\
\hline Seed treatment & $\begin{array}{l}\text { Seed treated by FIR method( } \\
\text { fungicide, Insecticide, and } \\
\text { Rhizobium spp. Carbendazim } 50 \% \\
\text { W.P @ } 2 \text { gram } / \mathrm{Kg}+\text { Chloropyripos } \\
20 \text { EC @ } 5 \mathrm{ml} / \mathrm{kg} \text { of seed + } \\
\text { Rhizobium and PSB @ } 500 \text { gram/ha } \\
\text { (8-12 hours interval each method) }\end{array}$ & No seed treatment. \\
\hline Fertilizes dose & $\begin{array}{l}\left(20 \mathrm{kgN}, 40 \mathrm{kgP}_{2} \mathrm{O}_{5}: 20 \mathrm{~kg} \mathrm{~K} \mathrm{~K}_{2} \mathrm{O}, 15 \mathrm{~kg}\right. \\
\text { Sulphur and } 10 \mathrm{~kg} \text { Boron. }\end{array}$ & $100 \mathrm{DAP} / \mathrm{ha}$ \\
\hline Plant protection & $\begin{array}{l}\text { Need based used of Saaf } \\
\text { (carbendazim } 12 \%+\text { mancozeb63\%) } \\
\text { for fungal disease and Imidacloprid } \\
17.8 \text { SL to protect the crop against } \\
\text { aphid. }\end{array}$ & Nil. \\
\hline $\begin{array}{l}\text { Weed } \\
\text { management }\end{array}$ & $\begin{array}{l}\text { Pendamathilian@0.3 kg a.i/ha pre } \\
\text { emergence followed by one hand } \\
\text { weeding at 35DAS. }\end{array}$ & $\begin{array}{l}\text { Two hand weeding at } 25 \text { and } \\
\text { 40DAS. }\end{array}$ \\
\hline
\end{tabular}

Table.2 Productivity, technology gaps, extension gaps and technology index of Lentil (HUL-57) grown under CFLDs and existing package of practices.

\begin{tabular}{|c|c|c|c|c|c|c|c|c|c|}
\hline \multirow[t]{2}{*}{ Year } & \multirow{2}{*}{$\begin{array}{c}\text { Area } \\
\text { (ha) }\end{array}$} & \multirow{2}{*}{$\begin{array}{c}\text { No.of } \\
\text { beneficiary }\end{array}$} & \multicolumn{3}{|c|}{ Grain Yield(Q/ha) } & \multirow{2}{*}{$\begin{array}{c}\% \\
\text { increase } \\
\text { Over } \\
\text { control }\end{array}$} & \multirow{2}{*}{$\begin{array}{l}\text { Technology } \\
\operatorname{gap}(q / h a)\end{array}$} & \multirow{2}{*}{$\begin{array}{l}\text { Extension } \\
\operatorname{gap}(\mathbf{q} / \mathbf{h a})\end{array}$} & \multirow{2}{*}{$\begin{array}{l}\text { Technology } \\
\text { index }(\%)\end{array}$} \\
\hline & & & Potential & $\begin{array}{l}\text { CFL } \\
\text { D }\end{array}$ & Control & & & & \\
\hline 2017-18 & 10 & 25 & 15.30 & 14.87 & 10.00 & 48.70 & 0.43 & 4.87 & 2.81 \\
\hline 2018-19 & 30 & 100 & 15.30 & 14.25 & 08.67 & 64.35 & 1.05 & 5.58 & 6.86 \\
\hline 2019-20 & 20 & 58 & 15.30 & 13.08 & 10.80 & 21.00 & 2.22 & 2.28 & 14.50 \\
\hline \multicolumn{4}{|c|}{ Average $=$} & 14.07 & 9.82 & 44.68 & 1.23 & 4.24 & 8.06 \\
\hline
\end{tabular}


Table.3 Economic analysis of demonstration and farmers practices

\begin{tabular}{|c|c|c|c|c|c|c|c|c|c|c|}
\hline \multirow[t]{2}{*}{ Year } & \multicolumn{2}{|c|}{$\begin{array}{c}\text { Cost of cultivation } \\
\text { (Rs/ha) }\end{array}$} & \multicolumn{2}{|c|}{$\begin{array}{c}\text { Gross } \\
\text { Return(Rs/ha) }\end{array}$} & \multicolumn{2}{|c|}{ Net Return(Rs/ha) } & \multirow[t]{2}{*}{$\begin{array}{l}\text { Additional } \\
\text { cost(Rs/ha) }\end{array}$} & \multirow{2}{*}{$\begin{array}{c}\text { Additional } \\
\text { Net Return } \\
\text { (Rs/ha) }\end{array}$} & \multicolumn{2}{|c|}{ B:C Ratio } \\
\hline & CFLD & FP & CFLD & FP & CFLD & FP & & & CFLD & FP \\
\hline 2017-18 & 24200 & 19500 & 81785 & 55000 & 57585 & 35500 & 4700 & 22085 & 3.38 & 2.82 \\
\hline 2018-19 & 19600 & 16006 & 58800 & 37980 & 39200 & 21974 & 3594 & 17226 & 3.00 & 2.37 \\
\hline 2019-20 & 20129 & 19840 & 73356 & 59400 & 52422 & 38860 & 289 & 13562 & 3.64 & 2.99 \\
\hline
\end{tabular}

The result of Cluster Front Line Demonstrations convincingly brought out that the yield of lentil could be increased by $21 \%$ to64.35\% with the intervention of balanced nutrient coupled with the improved seed and disease management in the Darbhanga district of Bihar. The input and output prices of commodities prevailed during each year of demonstration were taken for calculating cost of cultivation, net return and benefit cost ratio (Table 3). The net return from recommended practices was Rs. 39200 to Rs.57585 while the net return from farmer practices was Rs. 21974 to Rs. 38860. It means that net return from demonstration was higher than the farmer practices. The additional cost of Rs. 289 to 4700 gave additional net return; it ranged Rs. 13562 to Rs. 22085 per hectare. Thus, and it was clearly showed that the demonstration of lentil with full package was better than farmer's practices. Similar result has been reported by earlier by Teggelli et al., (2015).

From the above finding, it can also be concluded that use of scientific methods of lentil cultivation can reduced the technology gap to a considerable extent thus leading to increased productivity of the district. Moreover, extension agencies in the district need to provide proper technology support to the farmers through different educational and extension methods to reduce the extension gap for higher pulses production in the Darbhanga district of Bihar.

\section{References}

Ali, M. and Kumar, S. (2007). Pulses: Good option for rainfed area, The Hindu Survey of Indian Agril, 39-41.

Choudhary, BN. 1999. Krishi Vigyan KendraA guide for KVK managers. Division of Agricultural Extension, ICAR., pp 7378.

Duwayri, M., Tran, D. V. and Nguyen, V. N. (2000). Reflections on yield gaps in rice production: How to narrow the gaps, In: M. K., Papadimitriou, F. J. Dent Herath (eds) Bridging the yield gap in the AsiaPacific region, FAO Regional Office for Asia and the Pacific, Bangkok, Thailand.

Evans (1993). Crop Evolution, Adaptation, and Yield Cambridge University Press, Cambridge, UK; pp. 438-439.

Evans, L. T. (1993). Crop Evolution, Adaptation and Yield, Cambridge University Press, Cambridge.

Evans, R.A. Fischer (1999). Yield potential: its definition, measurement, and significance Crop Sci., 39 (1999), pp. 1544-1551

Gurumukhi, DR and Mishra Sumit.2003. Sorghum front line demonstration-A success story. Agriculture Extension Reviev, 15: 22-23.

Gurumukhi, DR and Mishra Sumit.2003. Sorghum front line demonstration-A success story. Agriculture Extension Reviev, 15: 22-23

Kirar, B.S., Mahajan, S.K. and Nashine, R. (2004). Impact of technology practices on the productivity of soybean in FLD. Indian Res. J. Ext. Edu., 5(1): 15-17

Kokate, K.D., Singh, A.K. and Singh Lakhan (2013). Harnessing pulses productivity 
for food and nutritional security. Indian Research Journal of Extension Education, 13 (1): January, 2013 pp.

Kumar Asheesh and Elamathi, S. (2007). Effect of nitrogen levels and rhizobium application methods on yield attributes, yield and economics of black gram (Vigna mungo L.), International Journal of Agril Sci., 3(1): $179-180$

Mitra and Samajdar, T (2010) Yield gap analysis of rapeseed -mustard through front line demonstration .Agri Extension Review; 22: 16-17.

Mitra, Biplab and Samajdar, T. (2010). Yield gap analysis of rapeseed-mustard through Front Line Demonstration. Agric. Exten. Reviev, (April-June):16-17

Mukherjee, N. (2003). Participatory learning and action Concept Publishing Company, New Delhi. Pp. 63-65.

Price, G. K. Landes, R. and Govindan, A. (2003). Electronic Outlook report from the Economic Research Service, WRS03-01, USDA.

Price, G. K. Landes, R. and Govindan, A. (2003). Electronic Outlook report from the Economic Research Service, WRS03-01, USDA.: Pp. 18-21.

Rajiv and Singh, L (2014). Performance of pulses demonstration Bundelkhand Zone of Uttar Pradesh, India, Indian Journal of App Research, 4(3): 1.

Reddy, A. (2004). Consumption pattern, trade and production potential of pulses. Economic and Political Weekly. October. Pp. 4854-60

Samui, S. K., Mitra, S., Roy, D. K., Mondal, A. K. and Saha, D. (2000). Evaluation of front line demonstration on ground nut (Arachis hypogea L.), Journal of Indian Society of Coastal Agriculture Research, 18: 180-83.

Sharma, OP. 2003. Moth bean yield improvement through Front Line Demonstrations. Agric Ext Rev, 15: 1113.

Singh, N., Kaur, H. and Singh, R. (2001). A Diagnosis on Area, Productivity and Production of Pulses in India. Indian Journal of Agricultural Economics, 57(3): 393-394.

Teggelli, Raju G., Patil, D.H., Naik, Ananda, Zaheer Ahamed, B. and Patil, M.C. (2015). Impact of front line demonstration on the yield and economics of pigeonpea in Kalaburgi district of Karnataka State. I.J.S.N., 6(2):224-227

Tiwari, RB; Singh, Vinay and Parihar, P. (2003). Role of FLD in transfer of gram production technology. Maharashtra $J$ Ext. Edu, 22: 139.

Tiwari, RB; Singh, Vinay and Parihar, P. 2003. Role of FLD in transfer of gram production technology. Maharashtra $J$ Ext. Edu, 22: 139.

Tomer, LS; Sharma, BP and Joshi, K. 2003. Impact of Front Line Demonstration of soybean in transfer of improved technology. J Ext Edu, 22: 139.

Van Ittersum, R. Rabbinge. (1997). Concepts in production ecology for analysis and quantification of agricultural inputoutput combinations, Field Crops Res., 52, pp. 197-208.

\section{How to cite this article:}

Ram Prawesh Prasad, D. Shekhar, M.S. Kundu, Amba Kumari and Chandan Kumar. 2020. Evaluation of yield performance of Lentil (Lens culinaris Linn) through Cluster Front Line Demonstration in Darbhanga District of Bihar, India. Int.J.Curr.Microbiol.App.Sci. 9(08): 1904-1910. doi: https://doi.org/10.20546/ijcmas.2020.908.218 